\title{
Pemulihan Kondisi Fisiologis, Konsumsi Pakan dan Bobot Badan Domba Ekor Tipis pada Umur Muda dan Dewasa Pasca Transportasi pada Siang Hari
}

\section{The Recovery Condition of Physiology, Feed Intake and Body Weight of Thin Tailed Lambs and Rams After Daylight Transportation}

\author{
T. Nelvita, A. Purnomoadi, dan E. Rianto
}

Fakultas Peternakan dan Pertanian, Universitas Diponegoro Semarang

Corresponding e-mail: agung194@yahoo.com

\begin{abstract}
The aim of this study was to examine the physiological recovery terms (heart rate, respiratory frequency, and rectal temperature), feed intake, and body weight on lambs and rams after 8 hours of daylight transportation from 11.00a.m - 19.00p.m. This research was conducted in Boja and Semarang. Twelve thin-tailed rams consisted of 6 lambs 3 - 4 months old (average body weight $15.03 \mathrm{~kg}$ ) and 6 rams $10-11$ months old (average body weight $23.87 \mathrm{~kg}$ ). The data was analyzed by using t- test to compare the recovery rate on physiological terms, feed intake, and body weight of the lambs and rams. The physiological recovery of the lambs and rams was not significantly different $(\mathrm{P}>0.05)$ where the lambs recovered in 4 days and rams in 5 days after. The feed intake recovery was not significantly different $(\mathrm{P}>0.05)$ where the lambs and rams recovered in 4 days after. Both lambs and rams were not significantly different $(\mathrm{P}>0.05)$ to recover the body weight in 5 days after. It is recommended that the feed used during the post-transport recovery should be as same as feed at the origin, thus the recovery time will be faster because the livestock does not need to adapt with the feed.
\end{abstract}

Key words: Sheep, transportation, recovery

\begin{abstract}
ABSTRAK
Penelitian ini bertujuan mengetahui lama pemulihan fisiologis (denyut nadi, frekuensi nafas dan suhu rektal), konsumsi pakan dan bobot badan pada domba muda dan dewasa pasca transportasi pada siang hari selama 8 jam dari pukul 11.00 - 19.00 WIB. Penelitian ini dilakukan di dua tempat yaitu Boja dan Semarang. Materi yang digunakan dalam penelitian ini adalah 12 ekor domba ekor tipis jantan yang terdiri dari 6 ekor domba muda kisaran umur $3-4$ bulan dengan kisaran bobot badan $13-16 \mathrm{~kg}$ (rata-rata 15,03 kg) dan 6 ekor domba dewasa umur 10 - 11 bulan dengan kisaran bobot badan $21-25 \mathrm{~kg}$ (rata-rata 23,87 kg). Data hasil penelitian dianalisis menggunakan uji $\mathrm{t}$, yaitu membandingkan kecepatan pemulihan fisiologis, konsumsi dan bobot badan antara domba muda dengan dewasa. Hasil penelitian menunjukkan bahwa lama pemulihan fisiologis ternak meliputi denyut nadi, frekuensi nafas dan suhu tubuh antara domba muda dan dewasa tidak berbeda nyata $(\mathrm{P}>0,05)$ untuk domba muda 4 hari dan dewasa 5 hari. Waktu pemulihan konsumsi antara domba muda dan dewasa tidak berbeda nyata $(\mathrm{P}>0,05)$ untuk domba muda dan dewasa 4 hari. Lama pemulihan bobot badan antara domba muda dan dewasa tidak berbeda nyata $(\mathrm{P}>0,05)$ untuk domba muda dan dewasa 5 hari. Disarankan pakan yang digunakan selama pemulihan pasca transportasi sama dengan pakan awal di tempat asal, sehingga waktu pemulihan lebih cepat dan ternak tidak perlu beradaptasi lagi dengan pakan.
\end{abstract}

Kata kunci : Domba, transportasi, pemulihan.

\section{PENDAHULUAN}

Transportasi memiliki peran penting di dalam usaha peternakan terutama dalam proses pemasaran, pengiriman ternak baik antar kota, provinsi, pulau bahkan antar negara. Proses transportasi yang dilakukan pada siang hari mempengaruhi temperatur di dalam alat transportasi menjadi tinggi akibat radiasi matahari, sehingga menyebabkan ternak mengalami cekaman (stres) yang dapat mengganggu kondisi fisiologis tubuh. Forrest et al. (1975) menyatakan bahwa cekaman dapat disebabkan oleh suhu lingkungan yang terlalu panas atau dingin selama transportasi, perlakuan kasar, dan suara asing yang mengganggu.

Proses pengangkutan ternak dapat mengakibatkan stres, sehingga berpengaruh pada kondisi fisiologis yang ditunjukkan oleh 
adanya perubahan frekuensi nafas, denyut nadi dan suhu tubuh. Semakin besar perubahan atau gangguan fisiologis tersebut maka ternak memerlukan waktu pemulihan yang semakin lama. Karnadi (1999) menyatakan bahwa stres akibat transportasi dapat berlangsung lama dan menimbulkan peningkatan tekanan darah, denyut nadi, intake oksigen, dan gangguan pencernaan. Ramadhan (2016) menyatakan bahwa pemulihan fisiologis pasca transportasi pada domba yaitu $3-6$ hari.

Stres akibat transportasi dapat merugikan peternak, yaitu penyusutan bobot badan ternak (Wardiman, 2016). Purbowati (2009) menyatakan bahwa jarak yang dekat antara kandang dengan pasar akan mengurangi penyusutan bobot badan selama perjalanan karena cekaman (stres) yang dialami domba lebih kecil. Susutnya bobot badan domba setelah transportasi menyebabkan peternak perlu melakukan manajemen pemulihan. Wardiman (2016) menyatakan bahwa pemulihan bobot badan setelah transportasi memerlukan waktu sekitar 2 minggu. Pemulihan konsumsi membutuhkan waktu yang lebih cepat dibandingkan dengan pemulihan bobot badan. Penelitian ini bertujuan mengetahui lama pemulihan fisiologis (denyut nadi, frekuensi nafas dan suhu rektal), konsumsi pakan dan bobot badan pada domba muda dan dewasa setelah dilakukan transportasi.

\section{MATERI DAN METODE}

Penelitian ini dilaksanakan di dua tempat yaitu di Boja, Kendal, Jawa Tengah dan di kandang Fakultas Peternakan dan Pertaanian, Universitas Diponegoro pada bulan Oktober - November 2016.

Materi yang digunakan dalam penelitian adalah 12 ekor domba ekor tipis jantan yang terdiri dari 6 ekor domba muda kisaran umur $3-4$ bulan dengan kisaran bobot badan 13 - $16 \mathrm{~kg}$ (rata-rata $15,03 \mathrm{~kg}$ ) dan 6 ekor domba dewasa umur 10 - 11 bulan dengan kisaran bobot badan $21-25 \mathrm{~kg}$ (ratarata $23,87 \mathrm{~kg}$ ). Pakan yang diberikan selama penelitian adalah $50 \%$ hay kangkung dan
$50 \%$ konsentrat dihitung berdasarkan bahan kering (BK). Pakan kangkung dan konsentrat di diberikan secara bersamaan. Pakan diberikan secara ad libitum.

Peralatan yang digunakan dalam penelitian adalah timbangan berkapasitas 40 $\mathrm{kg}$ dengan ketelitian $1 \mathrm{~g}$ untuk menimbang ternak dan timbangan berkapasitas $7 \mathrm{~kg}$ dengan ketelitian $1 \mathrm{~g}$ untuk menimbang pakan, ember kapasitas 3 liter untuk pemberian pakan dan pemberian air minum, mobil pick up untuk transportasi domba. Thermometer rektal untuk mengukur suhu rektal pada domba, thermohygrometer untuk mengukur suhu lingkungan dan kelembapan, stetoskop untuk mengukur denyut nadi domba dan stopwatch untuk mengukur waktu selama pengukuran parameter fisiologis. serta alat tulis yang digunakan sebagai catatan data selama penelitian.

Penelitian dibagi dalam tiga tahap. Tahap pertama dilaksanakan di Boja, berupa pengambilan data awal penelitian dengan cara menimbang domba tiga hari sekali untuk mengetahui bobot badan awal sebelum transportasi dan pertambahan bobot badan (PBB). Pada tahap ini juga dilaksanakan pengambilan data konsumsi sebelum transportasi untuk mengetahui konsumsi awal domba, dan konsumsi air minum selama 7 hari. Konsumsi pakan (g/ekor/hari) dihitung dengan cara menimbang pakan yang diberikan dikurangi sisa. Selain itu juga dilakukan pengukuran fisiologis ternak dan lingkungan yang dilakukan setiap pukul $07.00,12.00,18.00$ dan 00.00 WIB untuk mengetahui kisaran normal. Tahap kedua transportasi dari Boja menuju Semarang yang dilakukan selama 8 jam, mulai dari jam 11.00 - 19.00. Selama transportasi domba diistirahatkan sebanyak 2 kali untuk pengambilan data meliputi fisiologis ternak dan lingkungan selama transportasi. Sesampainya di Semarang domba ditimbang untuk mengetahui bobot badan, pengukuran fisiologis ternak dan lingkungan setelah transportasi. Tahap ketiga dilakukan di kandang Fakultas Peternakan dan Pertanian, Universitas Diponegoro yaitu untuk 
pemulihan fisiologis, konsumsi dan bobot badan domba pasca transportasi.

\section{Parameter Penelitian}

Parameter utama yang diamati dalam penelitian ini adalah lama pemulihan fisiologis, konsumsi pakan (BK) dan bobot badan. Lama pemulihan fisiologis, konsumsi pakan dan bobot badan dihitung menggunakan satuan hari. Pemulihan bobot badan diperoleh dengan cara menimbang ternak setiap 2 hari sekali sampai didapatkan bobot badan domba yang sama atau lebih dari bobot badan awal atau sebelum transportasi. Ternak dikatakan pulih secara konsumsi apabila konsumsi pakan selama pemulihan sudah menyamai atau melebihi konsumsi pakan sebelum transportasi. Parameter pendukung dalam penelitian ini adalah penyusutan bobot badan setelah transportasi, pertambahan bobot badan harian $(\mathrm{PBBH})$, fisiologi lingkungan mikro dan makro sebelum, saat dan setelah transportasi. bobot badan menyamai atau melebihi bobot badan sebelum ditransportasikan.

\section{Analisis Data}

Data hasil penelitian dianalisis menggunakan uji $\mathrm{t}$ yaitu membandingkan kecepatan pemulihan fisiologis, konsumsi dan bobot badan antara domba muda dengan dewasa.

\section{HASIL DAN PEMBAHASAN}

\section{Kondisi Fisiologis Domba selama Transportasi}

Kondisi fisiologis domba muda dan dewasa selama transportasi ditampilkan pada Tabel 1.

Hasil penelitian menunjukkan bahwa frekuensi nafas domba selama transportasi mengalami kenaikan pada waktu pengukuran pukul 13.00 WIB, yaitu pada domba muda dari $47 \mathrm{kali} /$ menit menjadi $160 \mathrm{kali} / \mathrm{menit}$, dan pada domba dewasa dari $47 \mathrm{kali} / \mathrm{menit}$ menjadi $141 \mathrm{kali} /$ menit. Hasil penelitian ini menunjukkan bahwa transportasi siang berpengaruh pada frekuensi nafas domba muda dan dewasa. Peningkatan frekuensi nafas dilakukan untuk membuang panas tubuh, agar suhu internal tetap berada dalam kisaran normal. Menurut McDowell (1972) naiknya frekuensi pernafasan pada saat suhu lingkungan yang tinggi adalah hal penting untuk membuang panas tubuh yang berlebihan, sehingga ternak dapat mengatasi panas tubuhnya dengan cara mempercepat laju pernafasan.

Frekuensi nafas domba mengalami penurunan pada waktu pengukuran pukul 16.30 WIB, yaitu pada domba muda dari 160 kali/menit menjadi $18 \mathrm{kali} / \mathrm{menit}$, dan pada domba dewasa dari $141 \mathrm{kali} / \mathrm{menit}$ menjadi $30 \mathrm{kali} / \mathrm{menit}$. Domba muda mengalami penurunan frekuensi nafas lebih besar.

Tabel 1. Kondisi fisiologis domba muda dan dewasa selama transportasi

\begin{tabular}{ccccc}
\hline \multirow{2}{*}{ Perlakuan } & \begin{tabular}{c} 
Waktu \\
Pengukuran \\
\cline { 3 - 5 }
\end{tabular} & $\begin{array}{c}\text { Frekuensi nafas } \\
\text { (kali/menit) }\end{array}$ & $\begin{array}{c}\text { Denyut Nadi } \\
(\text { kali/menit })\end{array}$ & $\begin{array}{c}\text { Suhu rektal } \\
\left({ }^{\circ} \mathrm{C}\right)\end{array}$ \\
\hline Muda & 10.00 & 47 & 90 & 38,3 \\
& 13.00 & 160 & 76 & 38,9 \\
& 16.30 & 18 & 80 & 38,6 \\
\hline Dewasa & 19.00 & 47 & 118 & 39,4 \\
& 10.00 & 47 & 95 & 38,5 \\
& 13.00 & 141 & 94 & 38,7 \\
& 16.30 & 30 & 78 & 38,5 \\
& 19.00 & 33 & 85 & 39,6 \\
\hline
\end{tabular}


Penurunan frekuensi nafas dapat diakibatkan karena suhu di dalam pick up mengalami penurunan, yaitu dari $31,3^{\circ} \mathrm{C}$ menjadi $23,6^{\circ} \mathrm{C}$, sehingga respon ternak terhadap adanya penurunan suhu dapat dilihat dari penurunan frekuensi nafas. Hal ini sesuai dengan pendapat Herbut dan Angrecka (2012) bahwa suhu dan kelembaban lingkungan merupakan kedua faktor yang sangat mempengaruhi perubahan fisiologi ternak yaitu salah satunya frekuensi nafas.

Denyut nadi domba selama transportasi mengalami sedikit penurunan pada waktu pengukuran pukul 13.00 WIB, yaitu pada domba muda dari $90 \mathrm{kali} /$ menit menjadi $76 \mathrm{kali} /$ menit, dan pada domba dewasa dari $95 \mathrm{kali} /$ menit menjadi 94 kali/menit. Penurunan denyut nadi ini sebagai upaya umum ternak menurunkan produksi panas akibat cekaman dari suhu lingkungan yang tinggi. Al-Haidary (2004) menyatakan bahwa tantangan stres panas mengurangi denyut jantung pada ternak yang diam, dan pengurangan denyut jantung karena upaya umum untuk ternak menurunkan produksi panas. Denyut nadi domba mengalami kenaikan pada waktu pengukuran pukul 19.00 WIB, yaitu pada domba muda dari $80 \mathrm{kali} / \mathrm{menit}$ menjadi 118 kali/menit, dan pada domba dewasa dari 78 kali/menit menjadi $85 \mathrm{kali} / \mathrm{menit}$. Hal ini dapat disebabkan oleh kenaikan suhu yang terjadi pada pengukuran pukul 19.00 WIB tersebut (di Semarang). Hal ini sesuai dengan pendapat Frandson (1996) menyatakan bahwa denyut nadi ternak sangat dipengaruhi oleh suhu lingkungan sekitar

Suhu tubuh domba selama transportasi mengalami kenaikan pada waktu pengukuran pukul 13.00 WIB, yaitu pada domba muda dari $38,3{ }^{\circ} \mathrm{C}$ menjadi $38,9{ }^{\circ} \mathrm{C}$, dan pada domba dewasa dari $38,5^{\circ} \mathrm{C}$ menjadi $38,7{ }^{\circ} \mathrm{C}$. Di lain pihak, pada waktu pengukuran pukul 16.30 WIB suhu tubuh mengalami penurunan, yaitu pada domba muda dari $38,9{ }^{\circ} \mathrm{C}$ menjadi $38,6{ }^{\circ} \mathrm{C}$, dan pada domba dewasa dari $38,7{ }^{\circ} \mathrm{C}$ menjadi $38,5^{\circ} \mathrm{C}$. Perubahan suhu tubuh domba muda dan dewasa dapat disebabkan oleh perubahan suhu lingkungan yang terjadi selama transportasi. Suherman et al. (2013) menyatakan bahwa perubahan suhu udara, kelembapan udara, pergerakan udara dan radiasi matahari dapat mempengaruhi kondisi fisiologis ternak. Suhu tubuh selama transportasi pada domba muda dan dewasa masih dalam kisaran normal. Hal ini sesuai dengan Smith dan Mangkoewidjojo (1988) bahwa suhu rektal domba di daerah tropis berada pada kisaran $38,2-40{ }^{\circ} \mathrm{C}$, namun hasil penelitian Martawidjaja et al. (1984) pada domba muda diperoleh kisaran 39,01 $40{ }^{\circ} \mathrm{C}$.

\section{Pemulihan kondisi fisiologis, konsumsi pakan, dan bobot badan pada domba muda dan dewasa setelah transportasi}

Tabel 2. Lama Pemulihan fisiologis, konsumsi pakan dan bobot badan domba muda dan dewasa setelah transportasi

\begin{tabular}{lccc}
\hline \multicolumn{1}{c}{ Pemulihan } & Perlakuan & Hari & Rata-rata \\
\hline Frekuensi nafas (x/mnt) & Muda & $2-5$ & 4 \\
& Dewasa & $2-6$ & 4 \\
Denyut nadi (x/mnt) & Muda & $3-6$ & 4 \\
\multirow{3}{*}{ Suhu rektal $\left({ }^{0} \mathrm{C}\right)$} & Dewasa & $2-6$ & 5 \\
& Muda & $2-5$ & 4 \\
Konsumsi pakan $(\mathrm{kg} / \mathrm{ek})$ & Dewasa & $2-6$ & 5 \\
\multirow{3}{*}{ Bobot badan $(\mathrm{kg})$} & Muda & $2-6$ & 4 \\
& Dewasa & $2-5$ & 4 \\
& Muda & $3-6$ & 5 \\
\hline
\end{tabular}


Hasil penelitian menunjukkan bahwa lama pemulihan kondisi fisiologis ternak meliputi frekuensi nafas, denyut nadi dan suhu tubuh antara domba muda dan dewasa tidak berbeda nyata $(\mathrm{P}>0,05)$. Waktu pemulihan kondisi fisiologis yang sama diduga karena domba muda dan dewasa mempunyai kemampuan yang hampir sama terhadap lingkungan baru. Lama pemulihan kondisi fisiologis ternak dapat dipengaruhi oleh suhu dan kelembapan lingkungan di tempat baru. Puspita (2016) menyatakan bahwa lama pemulihan kondisi fisiologis ternak setelah mengalami transportasi dapat dipengaruhi oleh kemampuan adaptasi terhadap suhu dan kelembaban lingkungan baru.

Waktu pemulihan konsumsi antara domba muda dan dewasa tidak berbeda nyata $(\mathrm{P}>0,05)$. Hal ini dapat disebabkan oleh tingkat stres akibat cekaman panas yang dialami domba muda dan dewasa selama transportasi sama. Hal tersebut dilihat dari suhu rektal antara domba muda dan dewasa selama transportrasi yang relatif sama. Faktor lain yang dapat mempengaruhi lama pemulihan konsumsi adalah suhu dan kelembaban lingkungan di tempat baru. Hogan et al. (2007) menyatakan bahwa lingkungan dan situasi di tempat yang baru akan mempengaruhi konsumsi pakan setelah transportasi. Lama pemulihan bobot badan antara domba muda dan dewasa tidak berbeda nyata $(\mathrm{P}>0,05)$. Persamaan waktu pemulihan bobot badan pada domba muda dan dewasa dapat disebabkan oleh konsumsi pakan yang kembali normal sehingga bobot badan dapat pulih sama atau melebihi bobot badan sebelum pengangkutan. Kesamaan waktu pemulihan antara domba muda dan dewasa pada penelitian ini juga dapat disebabkan oleh besar penyusutan bobot badan pada domba muda dan dewasa yang relatif sama. Penyusutan bobot badan pada domba muda adalah $1,52 \mathrm{~kg}$ dan pada domba dewasa 1,40 kg. Baihaqi et al. (2011) menyatakan bahwa lama pemulihan bobot badan setelah transportasi dapat disebabkan karena besarnya penyusutan bobot badan yang dialami akibat transportasi.

\section{KESIMPULAN}

Berdasarkan hasil penelitian dapat disimpulkan bahwa lama pemulihan kondisi fisiologis, konsumsi pakan dan bobot badan pada domba ekor tipis antara umur muda dan dewasa yang ditransportasikan pada siang hari selama 8 jam adalah sama.

\section{DAFTAR PUSTAKA}

Al-Haidary. A. A. 2004. Physiological responses of naimey sheep to heat stress challenge under semi-arid environments. International of Agriculture and Biology. 06: 307309.

Baihaqi, M., S. Rahayu, dan B. Ramadhona. 2011. Lama rekondisi bobot badan domba ekor gemuk yang diberi ransum komplit pasca transportasi. Fakultas Peternakan, Institut Pertanian Bogor. Bogor : 98 -102.

Forrest, G.J., Aberle, H.B. Hendrick, M.D. Judge and R.A. Merkel. 1975. Principles of Meat Science. W.H. Freeman and Company, San Francisco.

Frandson, R. D. 1996. Anatomi dan Fisiologi Ternak. Edisi ke 4. Gadjah Mada University Press, Yogyakarta (Diterjemahkan oleh B. Srigandono).

Herbut, P dan S. Angrecka. 2012. Forming of temperature-humidity index (THI) and milk production of cows in the free-stall barn during the periode of summer heat. Anim. Sci. Papers and Report. 30( 4) : 363-372.

Hogan, J. P., J. P. Pethrick, dan C. J. Philips. 2007. The physiological and metabolic impacts on sheep and cattle of feed and water deprivation before and during transport. Nutr. Res. Rev. 20 : 17-28. 
Karnadi, J. 1999. Stres dalam Kehidupan Sehari-hari. Cermin Dunia Kedokteran. 123 : 20.

Martawidjaja, M. 1984. Pengaruh Musim dan Pencukuran terhadap Status Faali dan Produktivitas Domba Lokal. Fakultas Pasca Sarjana Jurusan Peternakan Universitas Gadjah Mada, Yogyakarta. (Tesis).

McDowell, R.E. 1972. Improvement of livestock production in warm climates. W. E. Freeman and Company, San Fransisco.

Purbowati., E. 2009. Usaha Penggemukan domba. Penebar Swadaya. Jakarta.

Ramadhan, A. F. 2016. Pengaruh Pemberian Vitamin Kompleks terhadap Pemulihan Fisiologi, Konsumsi dan Bobot Badan Kambing Kacang Pasca Transportasi. Fakultas Peternakan dan Pertanian,
Universitas Diponegoro, Semarang. (Skripsi).

Smith, J.B. dan S. Mangkoewidjojo. 1988. Pemeliharaan, Pembiakan dan Penggunaan Hewan Percobaan di Daerah Tropis. Cetakan Pertama. Universitas Indonesia Press. Jakarta.

Suherman, D., B. P. Purwanto, W. Manalu, dan I. G. Permana. 2013. Simulasi artificial neural network untuk menentukan suhu kritis pada sapi Fries Holland berdasarkan respon fisiologis. Fakultas Pertanian, Universitas Bengkulu, Bengkulu. J. Ilmu Ternak dan Veteriner. 18 (1) : $70-80$.

Wardiman. 2016. Pengaruh naungan selama transportasi terhadap penyusutan dan lama pemulihan bobot badan pada kambing kacang. Universitas Diponegoro. Semarang. (Skripsi). 